\title{
Niemann-Pick Disease, Type C1
}

National Cancer Institute

\section{Source}

National Cancer Institute. Niemann-Pick Disease, Type C1. NCI Thesaurus. Code C126864.

Type C Niemann-Pick disease associated with a mutation in the gene NPC1, encoding Niemann-Pick C1 protein. 